\title{
Organizational Culture and Corporate Sustainable Development: Evidence from Greece
}

\author{
Dr. Georgios A. Deirmentzoglou \\ University of Piraeus \\ 80 Karaoli \& Dimitriou St., 18534 Piraeus, Greece \\ Dr. Konstantina K. Agoraki \\ University of Piraeus \\ 80 Karaoli \& Dimitriou St., 18534 Piraeus, Greece \\ Dr. Andreas E. Fousteris \\ University of Piraeus \\ 80 Karaoli \& Dimitriou St., 18534 Piraeus, Greece
}

\begin{abstract}
This study investigates the relationship between organizational culture and corporate sustainable development (CSD). Organizational culture is measured based on the four types of culture of the competing values framework: i) clan, ii) adhocracy, iii) hierarchy and iv) market type, while CSD was examined as a construct of $i$ ) economic, ii) environmental and iii) social dimension. The survey on medium- and large-sized firms in Greece reveals that adhocracy and hierarchy type of organizational culture have a significant effect on CSD. Specifically, adhocracy type is positively related to the environmental dimension of CSD, while hierarchy type is positively related to the economic dimension of CSD.
\end{abstract}

Keywords: organizational culture; corporate sustainable development; competing values framework; Greece

\section{Introduction}

Over the past sixty years, human activities have changed ecosystems at a more rapid and extensive pace than in any comparable period in the history of humankind (Heikkurinen and Bonnedeahl 2013). The business world, as a major factor for environmental contamination, should take drastic actions (Senge 2007), and redefine its role towards society. Organizations have to establish social and ethical standards (Lindgreen and Swaen 2010) todeal with these challenges and achieve sustainable development (Deirmentzoglou et al. 2020a; Golja and Pauisic 2012; Vashchenko 2017).

Scholars suggest that an appropriate organizational culture can lead to a pathway for corporate sustainable development (CSD) (e.g., Heslin and Ochoa 2008; Linnenluecke and Griffiths 2010; Porter and Kramer 2011). The involvement and commitment of employees are essential in successful sustainable organizations (Wirtenberg et al. 2007); however, in different institutional environments, employees have different views of the importance of sustainability (Husted 2005; Parboteeah et al. 2012; Weller 2017). Companies that want to respond to environmental and social challenges will need to undergo significant changes in their organizational culture. The successful implementation of a sustainabilityoriented culture will result in the best possible outcomes for the economy, the environment, and society (Deirmentzoglou et al. 2020b).

This paper explores the relationship between organizational culture and CSD. In this study, organizational culture is measured based on the four types of culture of the competing values framework (CVF): i) clan, ii) adhocracy, iii) hierarchy and iv) market type, while CSD was examined as a construct of three dimensions: i) economic, ii) environmental and iii) social.

In a previous empirical research study, Linnenluecke et al. (2009) revealed that employees from the hierarchy type emphasized the economic dimension of corporate sustainability. Nevertheless, there was insufficient evidence to justify the relationship of employees from other organizational types to corporate sustainability; thus, these variables needed further study.

\section{Literature Review and Hypotheses Development}

\subsection{Organizational culture}

The notion of organizational culture emerged in the academic literature in the early 1980s and has evolved during the decades (Baumgartner 2009). 
Although, there is still a lack of a single definition (Zammuto et al. 2000); Sackman (1991) stated that there are as many definitions as are those who study organizational culture. While there are various meanings associated to the term of organizational culture, it is acknowledged that organizational culture refers to underlying shared values that provide employees with behavioral norms in the firm (Baird et al. 2007; Chatman and Jehn 1994).

According to Hofstede et al. (2010), organizational culture is defined as "the way in which members of an organization relate to each other, their work and the outside world in comparison to other organizations". Many researchers of culture (e.g., Hofstede et al. 2010; Schein 2010; Trompenaars and Hampden-Turner 2012), have been focused on determining the different levels of culture's depth. Schein (2010) culture consists of three levels: i) artifacts, ii) espoused values and iii) basic assumptions. Artifacts are elements easy to physically observe such as objects, buildings, documents, and gestures. Espoused values are the explicit beliefs, shared goals and philosophies. Finally, basic assumptions are implicit beliefs and values that are difficult to change and taken for granted.

The organizational culture usually determines four things in business companies. These are: i) the general relationship between employees and the organization, ii) their position on the purpose and the goals of the organization (Trompenaars and Hampden-Turner 2012), iii) the person who has the authority to decide and iv) the processes and rules should be established for the desired results (Hofstede et al. 2010).

As discussed above, implicit values are in the core of an organization's culture; thus values should be used to measure organizational culture. In this study, organizational culture was measured by using the competing values framework (CVF) of Cameron and Quinn (2011), which explores the competing values within an organization in two dimensions, the "flexibility vs control" and the "internal vs external orientation". The first dimension differentiates organizational values that emphasize dynamism, discretion, and flexibility from values related to control, order, and stability. The second dimension differentiates organizational values that emphasize internal orientation, unity, and integration from values related to external orientation, rivalry, and differentiation. These two dimensions form four distinct types of organizational culture: i) clan, ii) adhocracy, iii) hierarchy and iv) market.

In this paper, organizational culture was measured by using CVF, as it is a validated and empirically derived framework that includes most of the proposed organizational culture's dimensions (Cameron and Quinn 2011; Linnenluecke Griffiths 2010). Moreover, CVF has been previously used to discuss the relationship between organizational culture and corporate sustainability (e.g., Linnenluecke and Griffiths 2010).

\subsection{Corporate sustainable development}

Montiel and Delgado-Ceballos (2014), conducting a literature review of the last twenty years, concluded that there is no standard definition of CSD and that the origin of this concept is mainly linked to the Brundtland report. This statement leads to defining CSD as "meeting the needs of a firm's direct and indirect stakeholders without compromising its ability to meet the needs of future stakeholders as well" (Ketola 2010). The same concept is often called "3Ps" due to the three-fold "People, Planet, Profit", as it refers to the social, environmental and economic dimension of corporate sustainability (Kolk and van Tulder 2010; Majid and Koe 2012; McNamara et al. 2017).

A lot of empirical researches have used instruments to measure CSD and firm's performance (e.g., Ho et al. 2012; Ringov and Zollo 2007). Chow and Chen (2012) have collected primary data and created an instrument of fifteen observable and assessable indicators that measure the economic, environmental and social dimension of CSD. We use this framework as it has been proposed (e.g., Bansal 2005; Chan 2005) and validated in previous studies.

\subsection{Hypotheses}

Below, it is discussed how each of organizational culture types is related to the dimensions of corporate sustainable development.

\subsubsection{Hierarchy type}

The hierarchy type is characterized by stability, monitoring, bureaucracy and control, allows the maximization of production and focuses on economic performance and growth (Cameron and Quinn 2011). Organizations with this structure lack of flexibility and curiosity (fundamentals of innovation) and they might pursue sustainability initiatives regarding only the economic dimension of CSD (Senge and Carstedt 2001). The following hypothesis is proposed:

Hypothesis $\mathbf{1}\left(\mathbf{H}_{\mathbf{1}}\right)$ : Hierarchy type is positively related to the economic dimension of CSD.

\subsubsection{Clan type}

The clan type is characterized by human relation values and puts great emphasis on social capital, teamwork, employee development and interpersonal relations. 
Thus, organizations with clan type might pursue sustainability practices that are mainly associated with the social dimension of the CSD (Daily and Huang 2001; Dunphy et al. 2003; Gollan 2000; Wilkinson et al. 2001).Given the above, the following hypothesis is proposed:

Hypothesis $2\left(\mathbf{H}_{2}\right)$ : Clan type is positively related to the social dimension of CSD.

\subsubsection{Market type}

The market type place greater emphasis on human resources, goal achievement and environmental policies. Organizations with this type of culture try to increase resource efficiencies and develop external stakeholder relationships (Linnenluecke and Griffiths 2010). Thus, these organizations might pursue sustainability practices that are mainly related to the environmental and social dimensions of CSD. The following hypotheses are offered:

Hypothesis 3a $\left(\mathbf{H}_{3 \mathbf{a}}\right)$ : Market type is positively related to the environmental dimension of CSD. Hypothesis $\mathbf{3 b}\left(\mathbf{H}_{\mathbf{3 b}}\right)$ : Market type is positively related to the social dimension of CSD.

\subsubsection{Adhocracy type}

Adhocracy type is related to innovation, adaptability, visionary communication and creativity and puts great emphasis on the broader ecological and social environment. Thus, organizations with adhocracy type might pursue sustainability practices that are mainly related to the environmental and social dimensions of CSD. The following hypotheses are offered:

Hypothesis $4 \mathbf{a}\left(\mathbf{H}_{\mathbf{4}}\right)$ : Adhocracy type is positively related to the environmental dimension of CSD. Hypothesis $\mathbf{4 b}\left(\mathbf{H}_{\mathbf{4 b}}\right)$ : Adhocracy type is positively related to the social dimension of CSD.

\section{Methodology}

\subsection{Sample selection}

Data were derived from executives of medium- and large-sized companies in Greece. The survey's instrument was sent and collected by email during November 2015 and February 2016. A total number of 183 CEOs participated the research; however, 27 questionnaires had incomplete answers. Thus, 156 questionnaires were finally analyzed.

\subsection{Dependent variable - Corporate sustainable development}

The social, economic and environmental dimensions of CSD were rated by the CEOs by using 15 measuring items with a 7-point Likert scale. These items were adopted by Chow and Chen's (2012) framework of CSD. The reason for using this instrument was that it is validated, has observable indicators and it is more convenient to collect and compare information from companies of different industries and sizes.

\subsection{Independent variable - Organizational culture}

Organizational culture was measured by the OCAI questionnaire based on the CVF. The instrument has six questions that ask participants to distribute 100 points among four scenarios based on the similarity of their firm to the firm outlined in the description. Each of the four scenarios represents one of the four organizational culture types.

\subsection{Control variables}

The control variables of this study were executives' age, gender, education and the number of years working in the company. Furthermore, we used control variables concerning the organization such as size, industry, home country, financial performance and the number of years that an organization has operated.

\subsection{Data analysis}

SPSS was used for data analysis. The study used multiple linear regressions to test the proposed causal relationships, and statistical significance was set at the 0.05 level.

\section{Results}

\subsection{Relationships between organizational culture, CSD and control variables}

Before conducting the linear regression analysis, we checked the correlation coefficients between dimensions of CSD, organizational culture types, and control variables. The economic dimension of CSD was significantly correlated with length of stay $(r=0.241, \mathrm{p}<0.01)$, size $(\mathrm{r}=0.157, \mathrm{p}<0.05)$, financial performance $(\mathrm{r}=0.139, \mathrm{p}<0.05)$ and hierarchy $(\mathrm{r}=-$ $0.270, \mathrm{p}<0.01)$.

The environmental dimension of CSD was significantly correlated with size $(r=0.320, p<0.01)$, industry ( $r=0.144$, $\mathrm{p}<0.05)$, length of operation $(0.192, \mathrm{p}<0.05)$ and adhocracy type $(0.175, \mathrm{p}<0.05)$. 
The social dimension of CSD was significantly correlated with size $(r=0.378, p<0.01)$, length of operation $(r=0.187$, $\mathrm{p}<0.05)$ and market $(\mathrm{r}=-0.164, \mathrm{p}<0.05)$. The clan type had no significant correlation with any of the dimensions of CSD (Table 1\&2).

Table 1. Pearson correlation coefficients for organizational culture and CSD

\begin{tabular}{|c|c|c|c|c|c|c|c|}
\hline & 1 & 2 & 3 & 4 & 5 & 6 & 7 \\
\hline 1.Clan & 1 & & & & & & \\
\hline 2.Adhocracy & -.111 & 1 & & & & & \\
\hline 3.Hierarchy & ${ }^{-}$ & $\begin{array}{c}- \\
358 * *\end{array}$ & 1 & & & & \\
\hline 4.Market &. & .032 & $.145^{*}$ & 1 & & & \\
\hline $\begin{array}{l}\text { 5.Economic } \\
\text { dimension of } \\
\text { CSD }\end{array}$ & .076 & .106 & $.270^{-}$ & .001 & 1 & & \\
\hline $\begin{array}{l}\text { 6.Environmental } \\
\text { dimension of } \\
\text { CSD }\end{array}$ & .011 & $.175^{*}$ & -.138 & .014 & $.475 * *$ & 1 & \\
\hline $\begin{array}{l}\text { 7.Social } \\
\text { dimension of } \\
\text { CSD }\end{array}$ & .071 & .057 & -.135 & $\begin{array}{c}- \\
.164^{*}\end{array}$ & $.556 * *$ & $.572 * *$ & 1 \\
\hline
\end{tabular}

Table 2. Pearson correlation coefficients for control variables and CSD

\begin{tabular}{|c|c|c|c|c|c|c|c|c|c|c|c|}
\hline & 1 & 2 & 3 & 4 & 5 & 6 & 7 & 8 & 9 & 10 & 11 \\
\hline 1.Gender & 1 & & & & & & & & & & \\
\hline 2.Age & - & 1 & & & & & & & & & \\
\hline 3.Education & $\begin{array}{l}.287 * * \\
.105\end{array}$ & $\begin{array}{c}- \\
.303^{*} \\
*\end{array}$ & 1 & & & & & & & & \\
\hline 4.Length of stay & $-.174 *$ & $\begin{array}{c}.613^{*} \\
*\end{array}$ & $\begin{array}{c}- \\
.411 * \\
*\end{array}$ & 1 & & & & & & & \\
\hline 5.Size & .053 & .083 & $\begin{array}{c}.193 * \\
*\end{array}$ & -.011 & 1 & & & & & & \\
\hline 6.Industry & .003 & .026 & .066 & .093 & -.032 & 1 & & & & & \\
\hline $\begin{array}{l}\text { 7.Length of } \\
\text { operation }\end{array}$ & .009 & -.042 & -.017 & .100 & $.141 *$ & .077 & 1 & & & & \\
\hline $\begin{array}{l}\text { 8.Financial } \\
\text { performance }\end{array}$ & -.044 & -.005 & .032 & .029 & .024 & .033 & $\begin{array}{c}.176 \\
*\end{array}$ & 1 & & & \\
\hline $\begin{array}{l}\text { 9.Economic } \\
\text { dimension }\end{array}$ & -.104 & .120 & -.046 & $\begin{array}{c}.241 * \\
*\end{array}$ & $.157^{*}$ & .090 & .128 & $\begin{array}{c}.139 \\
*\end{array}$ & 1 & & \\
\hline $\begin{array}{l}\text { 10.Environmenta } \\
1 \text { dimension }\end{array}$ & .018 & -.016 & .108 & -.025 & $\begin{array}{c}.320^{*} \\
*\end{array}$ & $\begin{array}{c}.144 \\
*\end{array}$ & $\begin{array}{c}.192 \\
*\end{array}$ & .092 & $\begin{array}{c}.475^{*} \\
*\end{array}$ & 1 & \\
\hline $\begin{array}{l}\text { 11.Social } \\
\text { dimension }\end{array}$ & .028 & .073 & .083 & -.019 & $\begin{array}{c}.378 * \\
*\end{array}$ & .119 & .187 & .106 & $\begin{array}{c}.556^{*} \\
*\end{array}$ & $\begin{array}{l}.572 \\
* *\end{array}$ & 1 \\
\hline
\end{tabular}

A linear regression analysis was employed to examine the causal relationships between organizational culture and CSD. Only independent and control variables that had a significant correlation with the dependent variable were included in the model. The variance inflation factor (VIF) and tolerance statistics confirmed that multicollinearity was not a problem for the models below.

The first regression model significantly predicted economic dimension of CSD ( $F=5.028, p<0.01$ ), while $\mathrm{R}^{2}$ was 0.139 . In this model, hierarchy $(\mathrm{t}=-2.885, \mathrm{p}<0.01)$ significantly affected CSD. Length of stay $(\mathrm{t}=2.096, \mathrm{p}<0.05)$ also had a significant impact on economic dimension of CSD (Table 3). 
Table 3. Hierarchy type and control variables predicting economic dimension of CSD

\begin{tabular}{cccccc}
\hline Variable & $\boldsymbol{B}$ & $\boldsymbol{B}(\mathbf{S E})$ & $\boldsymbol{\beta}$ & $\boldsymbol{t}$ & $\boldsymbol{p}$ \\
\hline Constant & 4.013 & 0.594 & 6.757 & 0.000 \\
& \multicolumn{5}{c}{ ControlVariables } \\
Length of stay & 0.149 & 0.071 & 0.179 & 2.096 & 0.038 \\
Size & 0.220 & 0.162 & 0.113 & 1.359 & 0.176 \\
Financial & 0.104 & 0.088 & 0.098 & 1.178 & 0.241 \\
Performance & \multicolumn{5}{c}{ IndependentVariables } \\
Hierarchy & -0.026 & $0.009 \quad-0.246$ & -2.885 & 0.005 \\
\hline \multicolumn{5}{c}{$\mathrm{F}=5.028, \mathrm{p}=0.001, \mathrm{R}^{2}=0.139$} \\
\hline
\end{tabular}

The second regression model significantly predicted environmental dimension of $\operatorname{CSD}(\mathrm{F}=6.747, \mathrm{p}<0.01)$, while $\mathrm{R}^{2}$ was 0.165. In this model, Adhocracy $(\mathrm{t}=2.306, \mathrm{p}<0.05)$ significantly affected CSD. Size $(\mathrm{t}=3.977, \mathrm{p}<0.01)$ also had a significant impact on CSD (Table 4).

Table 4. Adhocracy type and control variables predicting environmental dimension of CSD

\begin{tabular}{cccccc}
\hline Variable & $\boldsymbol{B}$ & $\boldsymbol{B}(\mathbf{S E})$ & $\boldsymbol{\beta}$ & $\boldsymbol{t}$ & $\boldsymbol{p}$ \\
\hline Constant & 4.038 & 0.332 & \\
\multicolumn{5}{c}{ ControlVariables } \\
Size & 0.588 & 0.148 & 0.316 & 3.977 & 0.000 \\
Industry & 0.053 & 0.044 & 0.095 & 1.206 & 0.230 \\
Length of & 0.174 & 0.114 & 0.121 & 1.519 & 0.131 \\
operation & \multicolumn{5}{c}{ IndependentVariable } \\
Adhocracy & 0.019 & $0.008 \quad 0.182$ & 2.306 & 0.023 \\
\hline \multicolumn{5}{c}{$\mathrm{F}=6.747, \mathrm{p}=0.000, \mathrm{R}^{2}=0.165$} \\
\hline
\end{tabular}

The third regression model significantly predicted social dimension of CSD ( $F=8.487, \mathrm{p}<0.01)$, while $\mathrm{R}^{2}$ was 0.160 . In this model, market $(\mathrm{t}=-1.528, \mathrm{p}>0.05)$ did not significantly affected CSD at the 0.05 level; however, size $(\mathrm{t}=3.970$, $\mathrm{p}<0.01$ ) significantly affected CSD (Table 5).

Table 5. Market type and control variables predicting social dimension of CSD

\begin{tabular}{cccccc} 
Variable & $\boldsymbol{B}$ & $\boldsymbol{B}(\mathbf{S E})$ & $\boldsymbol{\beta}$ & $\boldsymbol{t}$ & $\boldsymbol{p}$ \\
\hline Constant & 4.446 & 0.381 & 11.681 & 0.000 \\
Size & 0.689 & 0.174 & 0.322 & 3.970 & 0.000 \\
Length of & 0.206 & 0.133 & 0.124 & 1.545 & 0.125 \\
operation & \multicolumn{5}{c}{ IndependentVariables } \\
Market & -0.012 & $0.008 \quad-0.122$ & -1.528 & 0.129 \\
\hline \multicolumn{5}{c}{$\mathrm{F}=8.487, \mathrm{p}=0.000, \mathrm{R}^{2}=0.160$} \\
\hline
\end{tabular}

\subsection{Hypothesis testing}

The results indicated that $\mathrm{H}_{1}$ was supported, as hierarchy type had a significant positive impact on economic dimension of CSD. $\mathrm{H}_{4 \mathrm{a}}$ was also supported, as adhocracy type had a significant positive impact on environmental dimension of CSD. However, $\mathrm{H}_{2}, \mathrm{H}_{3}$, and $\mathrm{H}_{4 \mathrm{~b}}$ were not supported.

\section{Conclusion and discussion}

This paper provided a closer examination of the linkage between organizational culture and CSD. Specifically, organizational culture was measured based on the four types of culture of CVF: i) clan, ii) adhocracy, iii) hierarchy and iv) market type, while CSD was examined as a construct of three dimensions: i) economic, ii) environmental and iii) social. 
The results indicated that the hierarchy type is positively related to the economic dimension of CSD. This finding is consistent with the previous study of Linnenluecke et al. (2009) that indicated the same result. The rationale of this result is based on the observation that organizations with hierarchy type characteristics focus more on economic performance and growth and lack of innovation that is fundamental for the other aspects of sustainability. Thus, organizations with a hierarchy type place greater emphasis on the economic dimension of CSD.

Moreover, the results indicated that the adhocracy type is positively related to the environmental dimension of CSD. Organizations with adhocracy type highlight the significance of the external environment. These organizations assume that their operations are not separate from the ecological environment; thus, it is rational to put greater emphasis on the environmental dimension of CSD.

The proposed relationships need further exploration, as this study has some limitations. One limitation is that we used data from only one country. It is proposed that future studies should examine organizations from other countries to confirm these results. Furthermore, future research should include not only subjective but also objective measures to evaluate CSD and organizational culture.

\section{References}

Baird, K., Harrison, G., \& Reeve, R. (2007). The culture of Australian organizations and its relation with strategy. Journal of International Business Studies, 15, 15-41.

Bansal, P. (2005). Evolving sustainability: a longitudinal study of corporate sustainable development. Strategic Management Journal, 26, 197-218.

Baumgartner, R. (2009). Organizational culture and leadership: preconditions for the development of a sustainable corporation. Sustainable Development, 17, 102-13.

Cameron, K., \& Quinn, R. (2011). Diagnosing and changing organizational culture: Based on the competing values framework. San Francisco: Jossey-Bass.

Chan, R. (2005). Does the natural-resource-based view of the firm apply in an emerging economy? A survey of foreign invested enterprises in China. Journal of Management Studies, 42, 625-72.

Chatman, J., \& Jehn, K. (1994). Assessing the Relationship Between Industry Characteristics and Organizational Culture: How Different Can You Be?. Academy of Management Journal, 37, 522-53.

Chow, W., \& Chen, Y. (2012). Corporate sustainable development: Testing a new scale based on the mainland Chinese context. Journal of Business Ethics, 105, 519-33.

Commission of the European Communities. (2003). Commission recommendation of 6 May 2003 concenring the definition of micro, small and medium-sized enterprises. Official Journal of the European Union, 124, 36-41.

Daily, B. \& Huang, S. (2001). Achieving sustainability through attention to human resource factors in environmental management. International Journal of Operations \& Production Management, 21, 1539-52.

Deirmentzoglou, G. A., Agoraki, K. K., \& Fousteris, A. E. (2020a). Managers' perceptions \& actions towards sustainable development: Environmental \& social practices in Greece. International Journal of Academic Management Science Research, 4(4), 38-43.

Deirmentzoglou, G. A, Agoraki, K. K., Fousteris, A. E., \& Pekka-Economou, V. (2020b). The impact of cultural values on corporate sustainable development practices. International Journal of Innovation and Research in Educational Sciences, 7(2), 92-107.

Dunphy, D., Griffiths, A., \& Benn, S. (2003). Organizational change for corporate sustainability: A guide for leaders and change agents of the future. London: Routledge.

Golja, T., \& Pauisic, M. (2012). New challenges in corporate governance: Linking M\&A and social responsibility. Information Management and Business Review, 4, 379-90.

Gollan, P. (2000). Human resources, capabilities and sustainability. In D. Dunphy, J. Benveniste, A. Griffiths, \& P. Sutton (Eds.),Sustainability: The corporate challenge of the 21st century (pp. 55-77). Sydney: Allen \& Unwin.

Heikkurinen, P., \&Bonnedahl, K. J. (2012). Corporate responsibility for sustainable development: a review and conceptual comparison of market- and stakeholder-oriented. Journal of Cleaner Production,43, 191-98.

Heslin, P., \& Ochoa, J. (2008). Understanding and developing strategic corporate social responsibility. Organizational Dynamics, 37, 125-44.

Ho, F. N., Wang, H-M. D., \& Vitell, S. J. (2012). A global analysis of corporate social performance: The effects of cultural and geographic environments. Journal of Business Ethics, 107, 423-33.

Hofstede, G., Hofstede, G. J., \& Minkov, M. (2010). Cultures and organizations: Software of the mind. New York: McGraw Hill. 
Husted, B. W. (2005). Culture and ecology: A cross-national study of the determinants of environmental sustainability. Management International Review, 45, 349-71.

Ketola, T. (2010). Five leaps to corporate sustainability through a corporate responsibility portfolio matrix. Corporate Social Responsibility \& Environmental Management, 17, 320-36.

Kim, Y., \& Kim S-Y. (2010). The influence of cultural values on perceptions of corporate social responsibility: Application of Hofstede's dimensions to Korean public relations practitioners. Journal of Business Ethics, 91, 485-500.

Kolk, A., \& van Tulder, R. (2010). International business, corporate social responsibility and sustainable development. International Business Review, 19, 119-25.

Lindgreen, A., \& Swaen, V. (2010). Corporate social responsibility. International Journal of Management Review, 12, $1-7$.

Linnenluecke, M., \& Griffiths, A. (2010). Corporate sustainability and organizational culture. Journal of World Business, 45, 357-66.

Linnenluecke, M., Russell, S., \& Griffiths, A. (2009). Subcultures and sustainability practices: The impact on understanding corporate sustainability. Business Strategy and the Environment, 18, 432-52.

Majid, I., \&Koe, W-L. (2012). Sustainable entrepreneurship (SE): a revised model based on triple bottom line (TBL). International Journal of Academic Research in Business and Social Sciences, 2, 293-310.

McNamara, T., Carapinha, R., Pitt-Catsouphes, M., Valcour, M., \&Lobel, S. (2017). Corporate social responsibility and employee outcomes: The role of country context. Business Ethics: A European Review,26, 413-27.

Montiel, I., \& Delgado-Ceballos, J. (2014). Defining and measuring corporate sustainability: are we there yet?.Organization\& Environment, 1-27.

Parboteeah, P., Addae, H. M., \& Cullen, J. (2012). Propensity to support sustainability initiatives: A cross-national model. Journal of Business Ethics, 105, 403-13.

Porter, M., \& Kramer, M. (2011). Creating shared value: How to reinvent capitalism and unleash a wave of innovation and growth. Harvard Business Review, 89, 62-77.

Ringov, D., \& Zollo, M. (2007). Corporate responsibility from a socio-institutional perspective: The impact of national culture on corporate social performance. Corportare Governance, 7, 476-85.

Sackman, S. (1991). Uncovering culture in organizations. Journal of Applied Behavioral Science, 27, 295-317.

Schein, E. (2010). Organizational Culture and Leadership. 4th ed.Jossey-Bass.

Senge, P. M. (2007). Waking the sleeping giant: Business as an agent for consumer understanding and responsible choice. Journal of Corporate Citizenship, 26, 25-7.

Senge, P. M., \&Carstedt G. (2001). Innovating our way to the next industrial revolution. MIT Sloan Management Review, 42, 24-38.

Trompenaars, F., \& Hampden-Turner, C. (2012). Riding the waves of culture: Understanding diversity in global business. London-Boston: Nicholas Brealey Publishing.

Vashchenko, M. (2017). An external perspective on CSR: What matters and what does not?.Business Ethics: A European Review, 26, 396-412.

Vitell, S., Paolillo, J., \& Thomas, J. (2003). The perceived role of ethics and social responsibility: A study of marketing professionals. Business Ethics Quarterly, 13, 63-86.

Weller, A. E. (2017). Aligning responsible business practices: A case study. Journal of Business Ethics, 26, 457-67.

Wilkinson, A., Hill, M., \& Gollan, P. (2001). The sustainability debate. International Journal of Operations \& Production Management, 21, 1492-1502.

Wirtenberg, J., Harmon, J., \& Fairfield, K. (2007). HR's role in building a sustainable enterprise: Insights from some of the world's best companies. Human Resource Planning, 30, 10-20.

Zammuto, R. F., Gifford, B., \& Goodman, E. A. (2000). Managerial ideologies, organization culture, and the outcomes of innovation. In N., Ashkanasy, C., Wilderoom, \& M., Peterson (Eds.) Handbook of Organizational Culture and Climate (pp. 261-78). Thousand Oaks, CA: Sage. 